\title{
The quality of medical services in primary healthcare centres in selected communes of the Lubelskie Voivodeship, as assessed by patients - preliminary reports
}

\begin{abstract}
Introduction. Family medicine has a growing responsibility for the health of an individual, and therefore of society as a whole. Establishing an efficient primary healthcare system requires devising an appropriate management strategy. Surveying the quality assessment of medical services is an important element that influences the future shape of the development and management strategy in communes due to the dynamically changing demographic and economic trends, which are leaving their mark on the functioning of local communities.

Aim. Evaluation of quality of medical services in primary healthcare centres in communes of Lubelskie Voivodeship.

Material and methods. The anonymous survey was conducted among 60 patients benefitting from the medical services provided in healthcare centres in Niemce (Niemce Commune, Lublin District). An original questionnaire in the form of a poll was used to assess the quality of services provided in primary healthcare centres.

Results. The results of surveys carried out among the patients of medical centres providing services in the field of primary healthcare (PHC) demonstrated the high level of satisfaction with the received services among the respondents. However, the accessibility of primary healthcare services outside the business hours of PHC centres and the functioning of prevention and health-education programmes need improvement.

Conclusions. Based on the survey results we can conclude that the quality assessment of medical services provided by PHC centres, carried out through the ongoing monitoring of patients' satisfaction, should be the most important indicator of changes in the management of primary healthcare.
\end{abstract}

Keywords: primary healthcare, satisfaction, medical services.

DOI: $10.1515 /$ pjph-2015-0050

\section{INTRODUCTION}

Health is defined as full physical, mental and social wellbeing, and not only as the lack of sicknesses or ailments [1], which constitutes a multifaceted individual and social value. The public's health influences its productive potential and the vital well-being of citizens. Currently, family medicine has a growing responsibility for the health of an individual, but also of society as a whole. An appropriately designed system of assessing patients' satisfaction with the received services is crucial to the increasing of standards and quality of the provided services. Surveying the quality assessment of medical services is an important element that influences the future shape of development and management strategy in communes due to the dynamically changing demographic and economic trends, especially apparent in small communities. Patients' satisfaction with care is among the most important indicators of its effectiveness. The quality of provided medical services should be one of the most fundamental determinants of changes in the management strategies of primary healthcare centres. Directions for these changes and the shape of the management strategy in primary healthcare centres should be based largely on quality assessment.

\section{AIM}

The aim of the study was to identify the views of patients about the quality of services provided in PHC centres operating in the small communities of the Lubelskie Voivodeship.

\section{MATERIAL AND METHODS}

The survey was conducted among patients benefitting from the medical services provided in healthcare centres in Niemce (Niemce Commune, Lublin County). The surveys were anonymous and voluntary, which had been highlighted

\footnotetext{
${ }^{1}$ Department of Hygiene, Medical University of Lublin, Poland

${ }^{2}{ }^{\text {st }}$ Department of Radiology, Medical University of Lublin, Poland

${ }^{3}$ Department of Public Health, Medical University of Lublin, Poland

${ }^{4}$ Ergonomics and Occupational Hygiene Department, Technical University of Lublin, Poland

${ }^{5}$ Department of Prevention of Digestive System Diseases, Nursing Institute, Jan Kochanowski University of Kielce, Poland

${ }^{6}$ Theory and Application of Text Chair, Faculty of Social Science, The John Paul II Catholic University of Lublin, Poland

${ }^{7}$ Jordan Family Health, Salt Lake City, United States of America
} 
in a questionnaire. An original questionnaire in the form of a poll was used to assess the quality of services provided in primary healthcare centres. This surveying tool was prepared in line with the rules and guidelines for the design of surveying tools for data collection during social surveys [2]. The respondents could mark their answers, and, in some questions, give their own remarks. The whole questionnaire was composed of the demographics section and 27 questions. The demographics section (demographics questions) included demographic data - gender, age, place of residence, education, frequency of visits to the centre and professional activity. The demographics section also encompassed the 1st question concerning the individual assessment of one's financial situation. The remaining questions were connected with respondents' opinions about staff (questions 2 and 3), diagnostics and treatment (questions 5, 6, 7, 8, 9, 10,11, 12, 16 and 17), visits to the surgery $(4,13,14$ and 19$)$, involvement of the relatives (question 18), social conditions (question 22), availability of services at night (question 25), prevention programmes implemented in the centre (question 26), changes in the centre (question 24) and assessment of the center management (question 27). In two open questions the respondents could enumerate what, in their opinion, was the best (question 20) and what was the worst (question 21) about the given centre. At the end of the questionnaire, the respondents were asked to make their remarks about any possible changes or improvements to the centre. A Likert scale was used in respect of questions $1,2,3,16,17,24,25$ and 27, which made it possible to get answers on the degree of acceptance or assessment of individual problems. No patient had any difficulties with answering the questions.

The collected data were analysed using descriptive-statistics methods, to verify the variability of responses to individual questions, and to include any possible non-responses. Next, data, patient characteristics and responses were tabulated. The grading of negative responses was reversed, which means that, in respect of all questions, higher totals indicated a higher level of satisfaction. A factor analysis (of main components with a varimax rotation) was used to isolate relations that shaped satisfaction levels. Variable scores were specified as a quotient of the scale total by the number of variables in the range. The resultant scores were calculated by adding points from respective questions and dividing the total by the number of questions. Internal consistency and reliability were assessed using Cronbach's alpha. An insignificant percentage (6.7\%) of data gaps (481) in the total number of possible responses (6900) was identified.

\section{RESULTS}

The conducted surveys involved sixty patients in primary healthcare centres operating in Niemce.

The vast majority of respondents were female $-43(71.6 \%)$, with only 17 men $(28.3 \%)$. The patients' ages ranged from 15 to 71 (43 years on average). Most of the respondents lived in rural areas - 57 individuals (95\%), while three persons declared that they lived in cities. The most numerous group were respondents with secondary education - 38 individuals, which made up $63.33 \%$ of the whole. The second most numerous group was people with higher education -17 individuals $(28.33 \%)$, while respondents with primary education formed the smallest group, with only 5 representatives (approx. 8.33\%).
In terms of employment, $58.33 \%$ of all respondents were retirees and pensioners (35 persons). Working persons comprised the second most numerous group $(21.66 \%)$ among those surveyed. Non-working individuals (students and the unemployed) made up $15 \%$ of all the surveyed people ( 9 in total). In three cases there were no responses concerning professional activity. The financial situation of the respondents was assessed on a 5-point scale, from very bad, bad and satisfactory, to good and very good. A little more than half of respondents -31 individuals $(51.66 \%)$ assessed their situation as good. $36.66 \%$ evaluated it as satisfactory, and $5 \%$ as bad. No respondent opted for the "very bad" answer. Four persons regarded their situation as very good. The vast majority of respondents -46 individuals $(76.66 \%)$ declared that they benefitted from medical services offered in a GP practice no more than several times a year. Approx. 21.66\% of the respondents did so several times a month. Only one person visited a GP once a week.

Responses (variables) obtained within the questionnaires prepared under the surveys were coded and then subjected to statistical analysis. Due to the number of surveyed individuals $(n=60)$ and associated data sets with distributions clearly deviating from the norm, the analysis employed distribution-free methods.

To evaluate the direction and intensity of correlation, Spearman's rank correlation coefficient was calculated, taking values from the $(-1,1)$ range, assuming that the closer the coefficient is to 1 (or -1 ), the stronger the correlation [3]. Spearman's rank correlation coefficient was used to specify the strength of correlations between the opinions of patients from respective groups and the selected problems associated with the quality of services provided in primary healthcare centres in Niemce (Lublin District).

Factor analysis was carried out in respect of the initial 16 questions in the questionnaire. The analysis of the main components conducted with a varimax rotation indicated eight factors with characteristic roots $>1$. Further analysis demonstrated that four factors did not contribute much to variance explanation, and thus were regarded as insignificant. The four remaining result factors constituted $46.8 \%$ of the variance value $(15.7,14.0,8.8$ and $8.3 \%$ respectively). The factor loading of the first factor $(\mathrm{k}=8)$ reflected the content referring to satisfaction with the care offered by a GP. The factor loading of the second factor $(\mathrm{k}=7)$ referred to satisfaction with service. The factor loading of the third factor $(k=6)$ referred to technical equipment. The factor loading of the third factor $(\mathrm{k}=5)$ was associated with potential gaps in information accuracy.

TABLE 1. The distribution of questionnaire values of patients' opinions on the quality of services.

\begin{tabular}{lccc}
\hline \hline & $\begin{array}{c}\text { Average } \\
\text { assessment } \pm \text { SD }\end{array}$ & $\begin{array}{c}\text { \% of positive } \\
\text { responses }\end{array}$ & $\begin{array}{c}\text { \% of negative } \\
\text { responses }\end{array}$ \\
\hline Satisfaction & $6.0 \pm 1.5$ & 60.0 & 4.5 \\
\hline $\begin{array}{l}\text { Satisfaction } \\
\text { with service }\end{array}$ & $6.5 \pm 1.2$ & 67.5 & 6.3 \\
\hline Social conditions & $4.1 \pm 2.2$ & 35.0 & 8.0 \\
\hline $\begin{array}{l}\text { No or wrong } \\
\text { information }\end{array}$ & $3.4 \pm 2.1$ & 40.1 & 29.5 \\
\hline
\end{tabular}


The distribution of four scales, the general result (average of four point ranges) and general satisfaction with services are presented in Table 1. Despite the relatively small percentage of patients reporting the highest scores (percentage ceiling), most patients found themselves in the upper distribution interval, indicating a high level of satisfaction with GP services offered in the centres in question. No differences in average assessment between patients defined by their age or gender were identified. The results in the form of Spearman's rank correlation coefficients between the analysed ranges are presented in Table 2. Statistically significant correlations were identified between the isolated ranges and the general level of satisfaction with treatment. The strongest correlations were discovered between satisfaction with treatment effectiveness and the level of information provided to patients. The weakest correction was identified between the range reflecting satisfaction with service and the level of technical equipment (Table 2).

As illustrated by the survey in question, patients were generally satisfied with their GPs. They also displayed universally high satisfaction with the general level of care.

TABLE 2. The correlation between the scales (Spearman's rank correlation coefficient).

\begin{tabular}{lcccc}
\hline \hline & Satisfaction & $\begin{array}{c}\text { Satisfaction } \\
\text { with service }\end{array}$ & $\begin{array}{c}\text { Social } \\
\text { conditions }\end{array}$ & $\begin{array}{c}\text { No or incorrect } \\
\text { information } \\
\text { provided }\end{array}$ \\
\hline Satisfaction & 0.59 & 0.40 & 0.29 & 0.73 \\
\hline $\begin{array}{l}\text { Satisfaction } \\
\text { with service }\end{array}$ & 0.39 & 0.18 & 0.51 \\
\hline $\begin{array}{l}\text { Social } \\
\text { conditions }\end{array}$ & & 0.37 & 0.44 \\
\hline $\begin{array}{l}\text { No or incorrect } \\
\text { information } \\
\text { provided }\end{array}$ & & & 0.39 \\
\hline
\end{tabular}

\section{DISCUSSION}

As a result of systemic changes there occurred a change in the way patients and medical services are perceived [4]. In a modern healthcare system, a new patient model has been adopted, whose main roles involve the evaluation of received medical services [5]. The social assessment of the healthcare system is an important measure of the condition of healthcare and the efficiency of this system in respect of exercising patients' rights, as well as access to and satisfaction with medical services [6]. Being aware of the evolution of opinions on the functioning of healthcare and its conditions requires the ongoing updating and developing of knowledge of causal links between the phenomena, especially under conditions of significant dynamics in the healthcare system and with other macro-social conditions $[6,7]$.

The results of the survey of general satisfaction with primary healthcare services illustrated in this paper indicate a generally high level of satisfaction with the received medical services among the patients from the Niemce Commune. The obtained results do not differ in principle from the results demonstrated by most surveys concerning similar subjects conducted in Poland and abroad. Marcinowicz et al. [8], having carried out a meta-analysis of ten papers devoted to patients' satisfaction with primary healthcare concluded that the level of satisfaction was high in all papers, and that the percentage of people positively assessing healthcare offered in outpatient clinics was much higher than of dissatisfied individuals. The number of patients dissatisfied with PHC services was small, but varied depending on the manner of data collection. According to all-Poland surveys conducted by Hupert [9], involving 327 patients from PHC outpatient clinics, the average percentage of patients who opted for a definitely positive assessment of different aspects of healthcare in outpatient clinics amounted to $62.7 \%$, while of those who made a negative assessment to $9.7 \%$. The high level of satisfaction with the services offered by PHC centres was also corroborated by surveys carried out in municipal agglomerations: among the patients of outpatient clinics in Lublin [10-17], Warsaw [6,14,18], Bydgoszcz [19] and Białystok [20]. As regards surveys conducted in district cities $[8,14,19,21,22]$, the percentages of people who had made a positive assessment of provided services were slightly higher than in the case of municipal agglomerations, e.g. Radzyń Podlaski (77\%), Giżycko (86.4\%). The reverse situation was only observed in surveys by Pyra et al.[10], which compared the quality assessments of PHC made by 114 patients from four cities/towns - Lublin, Kielce, Stalowa Wola and Krosno. In the paper in question, approx. $42 \%$ of respondents thought that the services were of medium quality, and only $7 \%$ of them assessed the services as top-level [10]. The original findings presented in this paper and quoted surveys indicate that patients benefitting from PHC services were largely satisfied with the provided services. Different data in terms of healthcare service satisfaction are presented by the results of surveys carried out in November 2005 by the Public Opinion Research Centre [23]. This survey involved 1026 people. A quarter of people receiving treatment under insurance experienced problems or difficulties with obtaining medical aid or counselling, or other services. In this group, difficulties were indicated mostly by patients from the largest cities (more than 500000 residents) - 49\%, while in smaller towns and rural areas, such problems were experienced by no more than a quarter of patients. Similar information can be found in a material drawn up by the Centre for Health Information Systems [24]. The survey involved a representative, nationwide, sample of 2223 individuals. The availability of GP's services was, in general, assessed very highly. It is also worth highlighting that in this survey, similarly to the previous one, relatively the highest number of people dissatisfied with the availability of GP's services can be found in big cities, among individuals with higher education, and white-collar workers, while the lowest number of such persons is identified among the residents of rural areas and people with primary education. Also public opinion surveys carried out under the Pol MONICA Program in 1991 and 2001 in Warsaw indicated that in 2001 only a third of respondents declared being satisfied with healthcare [6]. Similarly, in international surveys on the quality of healthcare, including access to it, Poland fares very poorly. In a ranking of 12 European countries published in 2005 [25], prepared by Health Consumer Powerhouse, a private company, on the basis of original surveys and official statistical data, the Polish healthcare system ranked worst in the eye of the consumer, obtaining 25 out of 65 possible points. Next to the United Kingdom, Hungary and Italy, Poland was classified at the bottom of the list. Another major survey that evaluated the Polish healthcare sector was the Global Reputation Study 2005, which aimed at measuring and comparing the reputation of 40 countries from the whole world [26]. It was evaluated how citizens evaluate the State's and private 
enterprises' activities in the field of healthcare. Unfortunately, the Polish healthcare sector was ranked the lowest. It appears that differences in healthcare assessment result from the fact that a significant percentage of respondents positively assess the quality of healthcare if their responses are based on their own experience. Meanwhile, in surveys in which a significant proportion of respondents formed their views on healthcare under the influence of popular opinions, this very critical assessment was largely influenced by the exposure of negative phenomena present in healthcare in the media [18]. It appears that the differences between the results obtained and quoted can stem from different surveying methods and utilised tools, as well as from the fact that patients' satisfaction is not a separate notion, but is closely connected to the place and topic of the survey. In such a situation, making a credible juxtaposition of the results obtained and those presented in quoted surveys will not present the full scale of the problem in question. The results presented in this paper have no equivalents on the local scale, nor in any available study. The resulting difficulties in comparing the results obtained with those quoted are associated with the place of conducting the survey. So far the problem of assessing patients' satisfaction with the quality of medical service provided within the primary healthcare system has been broadly analysed in both Polish and international publications in respect of large municipal agglomerations and cities with district rights. The aspects touched on this paper and surveyed at the commune level, as the smallest administrative unit, have no equivalent in the available literature. Surveying the quality of medical services is an important element that influences the future shape of the development and management strategies in communes where primary healthcare is more often than not the only available element of the healthcare system. The obtained results carry important guidelines for the development of strategies for amending PHC management, in the reality of commune resources, and can be a stimulus to initiating further research in this field.

All things considered, the results of this paper can become a valuable direction on the road to recognizing quality as the most important determinant of changes in the management strategies of primary healthcare in the regional aspect, and bring to light the existing gaps in the assessment of medical services in small towns.

\section{REFERENCES}

1. Bzdęga J, Gębska-Kuczerowska A. Epidemiologia w zdrowiu publicznym. Warszawa: Wydawnictwo Lekarskie PZWL; 2010.

2. Gruszczyński L. Kwestionariusze w socjologii. Budowa narzędzi do badań surveyowych. Katowice: Wyd. Uniwersytetu Śląskiego; 2003.

3. Watała C. Biostatystyka - wykorzystanie metod statystycznych w pracy badawczej w naukach biomedycznych. Bielsko-Biała: Alfa-medica Press; 2002.

4. Bojar I, Ostrowski T, Wdowiak L, et al. Lekarz rodzinny jako menedżer ochrony zdrowia. Now Lek. 2003;72(6):462-6.

5. Coulter A. The Autonomous Patient. Ending paternalism in medical care. London: The Nuffield Trust; 2003. p. 106-21.

6. Misiuna M. Zmiany ocen opieki zdrowotnej i ich społeczne zróżnicowanie. Zdr Publ. 2005;115(3):296-302.

7. Głowacka MD, Galicki J. Sprawne zarządzanie zakładem opieki zdrowotnej. Poznań: Wyd. Polskie Towarzystwo Nauk o Zdrowiu; 2010.

8. Marcinowicz L, Grębowski R. Ocena opieki lekarza rodzinnego w świetle badań jakościowych: poszukiwanie komponentów zadowolenia i niezadowolenia. Fam Med Prim Care Rev. 2008;10(2):173-9.

9. Hupert Z. Jakość w opiece medycznej: koncepcja pomiaru. Lublin: Instytut Medycyny Wsi; 2003.

10. Pyra K, Raganowski P, Jabłońska J, et al. Ogólna ocena usług medycznych oferowanych przez Zakłady Podstawowej Opieki Zdrowotnej w opinii pacjentów. Ann UMCS sectio D. 2007;62(Suppl. 18):275-9.

11. Steć A, Wołyniak M, Wdowiak L. Satysfakcja pacjentów z usług świadczonych przez wybrane niepubliczne zakłady opieki zdrowotnej. Probl Hig Epidemiol. 2007;88(3):272-6.

12. Bojar I, Ostrowski T, Wdowiak L. Satysfakcja pacjentów z usług podstawowej opieki zdrowotnej w mieście Lublin. Ann UMCS sectio D. 2004;:LIX(Suppl. 14):185-9.

13. Bojar I, Wdowiak L, Ostrowski T, et al. Dostępność poradni POZ w Lublinie w opinii pacjentów. Zdr Publ. 2004:114(3):304-6.

14. Wójcik M, Tomaszewski M, Ruciński $P$, et al. Stopień zadowolenia pacjentów z udzielanych świadczeń w poradni lekarza rodzinnego. Ann UMSC sectio D. 2003;LVIII(Suppl. 13):486-91.

15. Kulczycka K, Stychno E, Wdowiak L. Publiczne i niepubliczne zakłady podstawowej opieki zdrowotnej w opinii pacjentów. Ann UMSC sectio D. 2004;LIX(Suppl. 14):262-6.

16. Kulczycka K, Stychno E, Wdowiak L. Satysfakcja pacjentów korzystających z usług podstawowej opieki zdrowotnej po przeprowadzonej reformie ochrony zdrowia. Ann UMSC sectio D. 2004;LIX(Suppl. 14):267-70.

17. Pietryka-Michałowska E, Wdowiak L, Szymańska J. Lekarz pierwszego kontaktu w opinii pacjentów. Cz. II Oczekiwania pacjentów. Zdr Publ. 2006;116(2):250-4.

18. Miller M, Supranowicz P, Gębska-Kuczerowska A, et al. Ocena poziomu satysfakcji pacjentów jako element jakości pracy podstawowej opieki zdrowotnej. Pol Merk Lek. 2007;XXIII(137):367-70.

19. Buczkowski K, Klucz K, Dachtera-Frąckiewicz M, et al. Porównanie świadczeń zdrowotnych udzielanych w praktykach lekarza rodzinnego działających w środowisku akademickim, miejskim i wiejskim. Zdr Publ. 2005;115(1):45-8.

20. Marcinowicz L, Górska A, Chlabicz S. Przyczyny niezadowolenia pacjentów z opieki lekarza rodzinnego w świetle badań ankietowych analiza odpowiedzi na pytania otwarte. Prz Lek. 2007;64(9):559-62.

21. Marcinowicz L, Konstantynowicz J, Chlabicz S. The patient's view of the acceptability of the primary care in Poland. In J Quality Health Care. 2008;20(4):277-83.

22. Marcinowicz L, Chlabicz S. Improvement in the accessibility and organization of services of family physicians in a small town in Poland: a comparison of patient opinions between 1998 and 2002. Adv Med Scie. 2006;52:226-31.

23. CBOS: Niezadowolenie z opieki zdrowotnej. Komunikat z badań Centrum Badania Opinii Społecznej. Warszawa: CBOS; 2005.

24. CSIOZ: Dostępność świadczeń zdrowotnych w opinii Polaków - Raport z badan. Warszawa: Centrum Systemów Informacyjnych Ochrony Zdrowia; 2005.

25. Dąbrowska A, Janoś-Kresło M. Znaczenie jakości w usługach zdrowotnych. In: S. Doroszewicz, A. Zbierzchchowska (ed). Jakość w dokonaniach współczesnej ekonomiki i techniki. Warszawa: SGH, 2005.

26. Miller M, Supranowicz P, Gębska-Kuczerowska A, et al. Ocena poziomu satysfakcji pacjentów jako element jakości pracy podstawowej opieki zdrowotnej. Pol Merk Lek. 2007;XXIII(137):367-70.

\section{Corresponding author}

Daria Przybylska

Department of Hygiene, Medical University of Lublin

11Radziwiłłowska Str., Lublin

tel. +48814486130

E-mail: dr.przybylska@gmail.com 